\title{
PENDUGAAN PEWARISAN GENETIK KARAKTER MORFOLOGI HASIL PERSILANGAN F2 TANAMAN KEDELAI (Glycine max (L.) Merr. PADA CEKAMAN SALINITAS
}

\section{Fachrina Wibowo*, Rosmayati, Revandy I. M. Damanik}

Prodi Pascasarjana Agroekoteknologi Fakultas Pertanian USU Medan, 20155

*Corresponding author: nina.fachrina@gmail.com.

\begin{abstract}
ABSTRAK
Salinitas menjadi salah satu ancaman bagi sistem produksi bahan pangan, termasuk kedelai. Salah satu strategi untuk mengatasi dan mengeliminasi penurunan produksi kedelai akibat meluasnya salinitas adalah merakit varietas toleran salinitas melalui persilangan. Seleksi merupakan tahap yang sangat menentukan keberhasilan tujuan pemulia dalam perakitan varietas unggul, dimana progeni yang terpilih berdasarkan mekanisme toleransi selanjutnya akan digunakan dalam perakitan varietas kedelai tahan salinitas dan berdaya hasil tinggi.Tujuan dari penelitian ini untuk menduga pewarisan genetik karakter morfologi hasil persilangan $\mathrm{F}_{2}$ tanaman kedelai pada cekaman salinitas. Penelitian dilaksanakan di Rumah kasa kebun percobaan Fakultas Pertanian Universitas Sumatera Utara, pada bulan Februari 2015 sampai dengan November 2015. Benih yang digunakan pada penelitian ini adalah seluruh benih $\mathrm{F}_{2}$ kedelai dari dua hasil persilangan, Varietas Anjasmoro (A) dan Grobogan (G) sebagai tetua betina dan varietas Grobogan yang telah mengalami beberapa tahap seleksi teruji tahan salin sebagai tetua jantan $\left(\mathrm{N}_{1}, \mathrm{~N}_{2}\right.$, $\mathrm{N}_{3}, \mathrm{~N}_{4}, \mathrm{~N}_{5}$ ) sehingga didapatkan 9 kombinasi genotipe hasil persilangan yaitu: $A x N_{1}$, $\mathrm{AxN}_{3}, \mathrm{AxN}_{4}, \mathrm{AxN}_{5}, \mathrm{GxN}_{1}, \mathrm{GxN}_{2}, \mathrm{GxN}_{3}, \mathrm{GxN}_{4}, \mathrm{GxN}_{5}$ selanjutnya benih $\mathrm{F}_{2}$ tetua Anjasmoro, Grobogan, dan tetua N. Adapun metode penelitian yang digunakan adalah analisa Statistik Deskriptif, diman uji kenormalan sebaran data dan frekuensi genotipe generasi $\mathrm{F}_{2}$ dilakukan untuk masing-masing karakter dilanjutkan dengan uji heritabilitas. Hasil penelitian didapat pada hasil persilangan dari keempat karakter yang kemungkinan besar dapat terwariskan adalah karakter jumlah daun dan bobot biji per tanaman pada persilangan GxN.
\end{abstract}

\section{Kata Kunci: Pewarisan genetik, kedelai, Salinitas, karakter morfologi}

\section{PENDAHULUAN}

Salinitas menjadi salah satu ancaman bagi sistem produksi bahan pangan, termasuk kedelai. Respon tanaman terhadap cekaman garam mencangkup mekanisme toleran (tolerance) dan mekanisme penghindaran (avoidance). Mekanisme toleran mencangkup perubahan mekanisme morfologi, fisiologi, dan biokimia untuk menjaga viabilitas protoplasma sel. Pada mekanisme morfologi, disamping pertumbuhan yang tertekan, salinitas menyebabkan perubahan struktur yang khas dilakukan tanaman untuk memperbaiki status air tanaman seperti tinggi tanaman, jumlah daun, memperpendek umur berbunga dan umur tanaman, bobot kering, jumlah cabang produktif, jumlah polong, bobot bijidan laju pengisian biji.

Mekanisme ketahanan tanaman terhadap salinitas bervariasi antara spesies dan varietas dari tingkat yang paling rentan sampai paling tahan. 
Tanggapan tanaman terhadap lingkungan salin umumnya diakibatkan oleh adanya perubahan metabolisme (Farid dan Sjahril, 2006). Respon toleransi genotipe kedelai terhadap cekaman salinitas dapat berupa, 1.Pencegahan perpindahan ion dari akar menuju bagian lain tanaman, 2.Tidak mengakumulasi banyak garam pada daun dan batang, dan 3. Memiliki kemampuan penyesuaian osmotik yang lebih baik pada sel tanaman (Pathan et al. 2007).

Pertumbuhan kecambah

kedelai tercekam salinitas nyata menurunkan daya kecambah pada saat salinitas ekstrak larutan tanah mencapai $11 \mathrm{dS} / \mathrm{m}$.

Adanya peningkatan serapan $\mathrm{Na}+$ dan $\mathrm{Cl}$ pada kedelai varietas Lee dan Jakcson diduga akibat peningkatan konsentrasi $\mathrm{NaCl}$ pada larutan nutrisi. Perbedaan toleransi varietas kedelai terhadap salinitas seringkali berhubungan dengan toksisitas klorida (Adie dan Krisnawati, 2013). Salinitas berpengaruh pula terhadap hasil biji kedelai. Penurunan hasil sebanyak $20 \%$ dilaporkan terjadi pada salinitas tanah $4,0 \mathrm{dS} / \mathrm{m}$ dan mencapai $66 \%$ pada salinitas $5,4 \mathrm{dS} / \mathrm{m}$.

Hasil penelitian Nugraheni, pengaruh salinitas tinggi pada tanaman Crotalaria juncea L menunjukkan tinggi konsentrasi salinitas pertambahan tinggi tanaman semakin menurun yang diduga disebabkan oleh terlarutnya garam sehingga menurunkan potensial air, yang berakibat tanaman sulit menyerap, rusaknya membran sel, yang menyebabkan sifat selektivitas membran sel berkurang. Keadaan ini dapat mengakibatkan pengambilan ion menjadi berlebih dan dapat meracuni tanaman, sehingga dapat menghentikan pertumbuhan sel. Pada pengaruh berat kering, menurunnya berat kering diduga karena menurunnya laju fotosintesis. Salinitas menyebabkan kekurangan air pada tanaman terutama pada organ daun, sehingga mendorong penutupan stomata.
Penutupan stomata akan menghalangi masuknya $\mathrm{CO} 2$, sehingga menurunkan kecepatan fotosintesis. Menurunnya luas daun total merupakan tanggapan tanaman terhadap penyediaan air, penyediaan air ini diduga karena sel-sel daun yang masih muda dan sedang mengadakan pembentangan mengalami cekaman air akibat salinitas. Keadaan ini menyebabkan pembesaran dan pemanjangan sel muda yang tidak maksimal (Nugraheni et al. 2013).

Salah satu strategi untuk memanfatkan lahan salin adalah memilih genotipe kedelai yang toleran terhadap kadar garam yang tinggi. Pada penelitian ini karakter morfologi yang terjadi pada tanaman yang berpotensi toleran salin diharapkan dapat diturunkan keturunan selanjutnya dengan sebaran normal.

\section{BAHAN DAN METODE}

Penelitian ini dilaksanakan di Rumah kasa kebun percobaan Fakultas Pertanian Universitas Sumatera Utara. Dengan ketinggian tempat $\pm 25 \mathrm{~m}$ diatas permukaan laut, dilaksanakan pada bulan Februari 2015 sampai dengan November 2015.Bahan yang digunakan pada penelitian ini adalah seluruh benih $\mathrm{F}_{2}$ kedelai dari dua hasil persilangan, Varietas Anjasmoro (A) dan Grobogan (G) sebagai tetua betina dan varietas Grobogan yang telah mengalami beberapa tahap seleksi teruji tahan salin sebagai tetua jantan $\left(\mathrm{N}_{1}, \mathrm{~N}_{2}, \mathrm{~N}_{3}, \mathrm{~N}_{4}, \mathrm{~N}_{5}\right)$ sehingga didapatkan 9 kombinasi genotipe hasil persilangan yang tetap tumbuh dan berkembang pada $F_{2}$, yaitu: $A x N_{1}, A x N_{3}, A x N_{4}, A x N_{5}, G x N_{1}, G_{2}$, $\mathrm{GxN}_{3}, \mathrm{GxN}_{4}, \mathrm{GxN}_{5}$ selanjutnya benih $\mathrm{F}_{2}$ tetua Anjasmoro, Grobogan, dan tetua N ditanam bersamaan dengan benih hasil silang, TSP, $\mathrm{KCl}$, herbisida, fungisida dan insektisida sebagai bahan pendukung penelitian. Alat-alat yang digunakan Electroconductimeter, $\mathrm{pH}$ meter, timbangan analitik, oven, gelas 
erlenmeyer berbagai ukuran, corong, meteran, cangkul, gembor, amplop, label, alat tulis, serta alat lain yang mendukung penelitian ini.

\section{Metodologi Penelitian}

Metode penelitian yang digunakan adalah analisa Statistik Deskriptif. Uji kenormalan sebaran data dan frekuensi genotipe generasi $F_{2}$ dilakukan untuk masing-masing karakter menggunakan uji kenormalan dilanjutkan dengan uji heritabilitas. Analisis dilakukan dengan bantuan perangkat lunak Microsoft Excel dan Minitab versi 16.0. Adapun yang dianalisis dalam penelitian ini meliputi:

Nilai skewness dapat dihitung dengan rumus Pearson, yaitu:

$$
\mathrm{Sk}=\frac{\mathrm{X}-\mathrm{Mod}}{\mathrm{S}}
$$

Nilai kurtosis dapat dihitung berdasarkan momen ke empat, yaitu:

$$
\alpha_{4}=\frac{\text { Momen } 4}{\mathrm{~S} 4}
$$

dimana

sehingga

$$
\text { Momen } \mathrm{r}=\frac{\Sigma\left(\mathrm{X}_{i}-X\right)^{\mathrm{r}}}{\mathrm{n}}
$$

$\alpha_{4}<3$ : Platykurtik

$\alpha_{4}=3:$ Mesokurtik

$\alpha_{4}>3$ : Leptokurtik

$$
\begin{array}{ll}
\text { Keterangan } & : \\
\mathrm{X} & =\text { Rata- rata genotipe } \\
\Sigma \mathrm{X}_{\mathrm{i}} & =\text { Jumlah keseluruhan } \\
\text { data } & \\
\mathrm{S} & =\text { Standart deviasi } \\
\mathrm{Sk} & =\text { Skewness } \\
\alpha & =\text { Kurtosis } \\
\text { Mod } & =\text { Modus } \\
\text { Median } & =\text { Median } \\
\mathrm{n} & =\text { Banyak data genotipe }
\end{array}
$$

Pendugaan nilai heritabilitas diuji dengan

\begin{tabular}{|c|c|c|c|}
\hline \multicolumn{2}{|c|}{$\begin{array}{c}\text { Tabel Uji } \\
\text { Kenormalan Data }\end{array}$} & Bentuk Grafik & Keterangan \\
\hline Skewness & $=0$ & Sebaran Normal & Aksi gen aditif \\
\hline Skewness & $<0$ & Sebaran Tidak Normal & $\begin{array}{l}\text { Aksi gen aditif dengan pengaruh } \\
\text { epistatis duplikat }\end{array}$ \\
\hline Skewness & $>0$ & Sebaran Tidak Normal & $\begin{array}{l}\text { Aksi gen aditif dengan pengaruh } \\
\text { epistatis komplementer }\end{array}$ \\
\hline Kurtosis & $=3$ & Mesokurtik & \\
\hline Kurtosis & $<3$ & Platykurtik & Karakter dikendalikan oleh banyak gen \\
\hline Kurtosis & $>3$ & Leptokurtik & Karakter dikendalikan oleh sedikit gen \\
\hline
\end{tabular}
rumus, sebagai berikut:

$$
h^{2}=\frac{S^{2} F_{2}-\left(S^{2} P_{1}+S^{2} P_{2}\right) / 2}{S^{2} F_{2}}
$$

Tabel 1. Bentuk Grafik nilai skewness dan kurtosis yang diperoleh, dapat diarti dan dikarakterkan sebagai berikut

Keterangan:

$\begin{array}{ll}\mathrm{h}^{2} & =\text { heritabilitas } \\ \mathrm{S}^{2} \mathrm{~F}_{2} & =\text { Ragam Populasi } \mathrm{F}_{2} \\ \mathrm{~S}^{2} \mathrm{P}_{1} & =\text { Ragam populasi } \mathrm{P} 1 \\ \mathrm{~S}^{2} \mathrm{P}_{2} & =\text { Ragam populasi } \mathrm{P} 2\end{array}$

Kriteria nilai heritabilitas menurut Standfield, (1991) dikelompokkan sebagai berikut:

Rendah $\quad: h^{2}<0,2$

Sedang $\quad: 0,2<\mathrm{h}^{2} \leq 0,5$

Tinggi $\quad: h^{2}>0,5$ 


\section{Seleksi Benih}

Dipilih dengan melihat biji yang bernas, mengkilap dan tidak keriput.

\section{Persiapan Areal dan Media Tanam}

Areal tanam dibersihkan terlebih dahulu dari gulma yang tumbuh di daerah tersebut. Kemudian agar tanaman terlindung dari air hujan dipasang tenda plastik kaca sebagai naungan. Untuk media tanam tanah dimasukkan kedalam polibag.

Untuk media tanam tanah dimasukkan kedalam polibag sebanyak $10 \mathrm{~kg}$ tanah salin dengan DHL 5-6 mmhos/cm yang telah diukur sebelumnya. Tanah yang diambil dari darerah Kecamatan Percut Sei Tuan Desa Paluh Merbau dan Desa Paluh Getah.

\section{Penanaman}

Penanaman dilakukan dengan membuat lubang tanam di polibag dengan kedalaman tanah $\pm 2 \mathrm{~cm}$, kemudian memasukkan 2 benih/lubang tanam dan ditutup dengan tanah.

\section{Pemupukan}

Pemupukan dilakukan sesuai dosis anjuran kebutuhan pupuk kedelai yaitu $100 \mathrm{~kg}$ Urea/ha $(0,6 \mathrm{~g} / \mathrm{lubang}$ tanam), $200 \mathrm{~kg}$ TSP/ha (1,2 g/lubang tanam), dan $100 \mathrm{~kg} \mathrm{KCl} / \mathrm{ha}$ (0,6g/lubang tanam). Pemupukan dilakukan 2 kali pada saat penanaman dan umur 5 MST.

\section{Pemeliharaan Tanaman}

\section{Penyiraman dan penjagaan kadar salinitas}

Penyiraman dilakukan pada sore hari atau disesuaikan dengan kondisi tanah sebanyak $250 \mathrm{ml}$ air kedalam polibag melalui selang yang dimasukkan ketanah bertujuan agar air di dalam dan dipermukaan polibag seimbang. Penjagaan kadar DHL 5- $6 \mathrm{mmhos} / \mathrm{cm}$ dan $\mathrm{pH}<8,5$ tetap diperhatikan. Kadar Salinitas diukur sekali dalam seminggu menggunakan Electro Conductivity Meter.

\section{Penyiangan}

penyiangan dilakukan secara manual dengan mencabut gulma yang tumbuh disekitar areal tanam, didalam dan diluar polibag. Penyiangan dilakukan sesuai kondisi di lapangan.

\section{Pengendalian hama dan penyakit}

Pengendalian hama dilakukan dengan mengacu pada konsep PHT. Namun, jika hama melebihi ambang batas maka penyemprotan insektisida dengan dosis $0,5 \mathrm{cc} /$ liter air, sedangkan pengendalian penyakit dilakukan dengan menyemprot fungisida dengan dosis $1 \mathrm{cc} /$ liter air.

\section{Pemanenan}

Panen dilakukan dengan cara dicabut satu persatu setiap tanaman dengan menggunakan tangan. Adapun kriteria panen yaitu adalah ditandai dengan kulit polong sudah berwarna kuning kecoklatan sebanyak $95 \%$ matang fisiologis dan daun sudah berguguran tetapi bukan karena adanya serangan hama dan penyakit.

\section{Peubah Amatan}

Peubah amatan meliputi: persentase perkecambahan, tinggi tanaman $(\mathrm{cm})$, jumlah daun (helai), bobot kering akar $(\mathrm{g})$, dan bobot biji pertanaman $(\mathrm{g})$. 


\section{HASIL DAN PEMBAHASAN}

\section{Karakter Tinggi Tanaman $(\mathrm{cm})$}

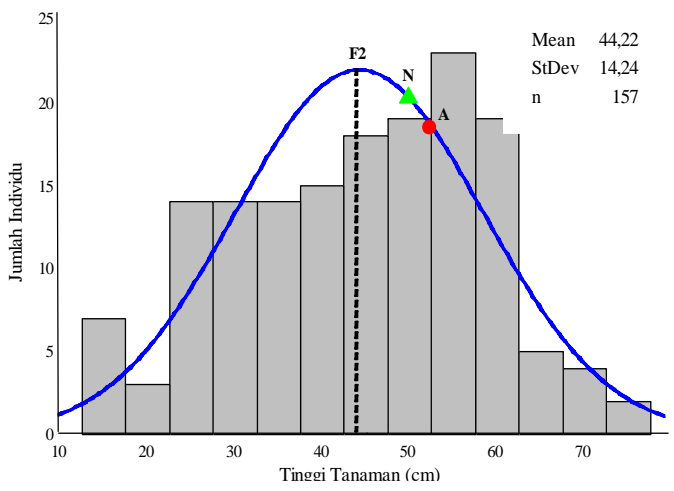

(a)

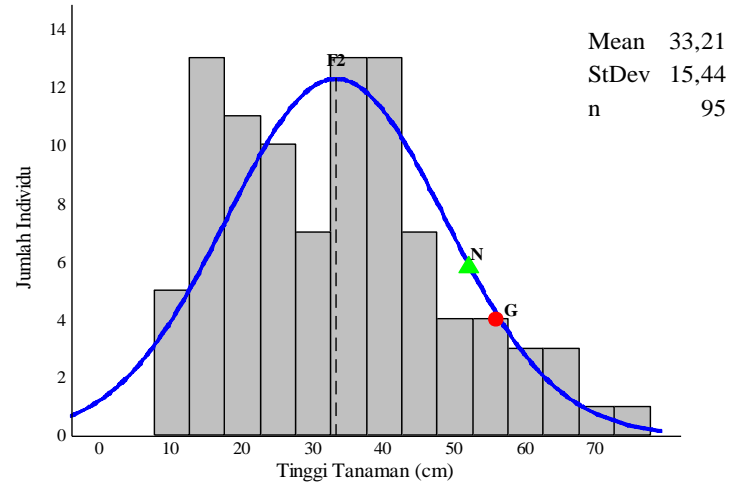

(b)

Gambar 1. Grafik Sebaran populasi F2, untuk karakter tinggi tanaman (cm) pada persilanagan (a) $\mathrm{AxN}$ (b) $\mathrm{GxN}$

Tabel 2. Pendugaan Aksi Gen Karakter Tinggi Tanaman (cm) melalui Nilai Skewness dan Kurtosis

\begin{tabular}{lllll}
\hline Persilangan & Skewnses & \multicolumn{1}{c}{ Keterangan } & Kurtosis & \multicolumn{1}{c}{ Keterangan } \\
\hline Ax N & $-0,149$ & $\begin{array}{l}\text { aksi gen aditif }+ \\
\text { epistasis duplikat } \\
\text { aksi gen aditif }+\end{array}$ & $-0,675$ & $\begin{array}{l}\text { Platykurtik+ } \\
\text { dikendalikan banyak gen } \\
\text { epistasis komplementer }\end{array}$ \\
\hline
\end{tabular}

Hasil pengamatan tinggi tanaman pada persilangan $\mathrm{AxN}$ (Gambar 1.a) menunjukkan hasil tidak berdistribusi normal. Jumlah individu terbanyak 23 individu dengan kisaran tinggi tanaman 52,5-57,5 cm. Hasil persilangan $\mathrm{AxN}$ memperlihatkan rataan tinggi tanaman $44,224 \mathrm{~cm}$ yang lebih rendah dari kedua tetuanya $\mathrm{N}(50,368 \mathrm{~cm})$ dan A $(52,383$ $\mathrm{cm}$ ). Pendugaan aksi gen (Tabel 2) diketahui nilai skewnees $<0$ menunjukkan grafik sebaran tidak normal artinya aksi gen aditif dengan pengaruh epistasis duplikat dan nilai kurtosis < 3 yang menunjukkan bentuk grafik platykurtik artinya karakter dikendalikan oleh banyak gen.
Hasil pengamatan tinggi tanaman pada persilangan GxN (Gambar 1.b) menunjukkan hasil tidak berdistribusi normal. Jumlah individu terbanyak berjumlah 13 individu dengan kisaran tinggi tanaman 37,5-42,5 cm. Hasil persilangan $\mathrm{GxN}$ memperlihatkan rataan tinggi tanaman 33,206 $\mathrm{cm}$ yang masih lebih rendah dari kedua tetuanya $\mathrm{N}$ $(50,959 \mathrm{~cm})$ dan $\mathrm{G}(56,509 \mathrm{~cm})$. Pendugaan aksi gen (Tabel 2) diketahui nilai skewnees $>0$ yang menunjukkan grafik sebaran tidak normal artinya aksi gen aditif dengan pengaruh epistasis komplementer dan nilai kurtosis < 3 yang menunjukkan bentuk grafik platykurtik artinya karakter dikendalikan oleh banyak gen. 


\section{Karakter Jumlah Daun (helai)}

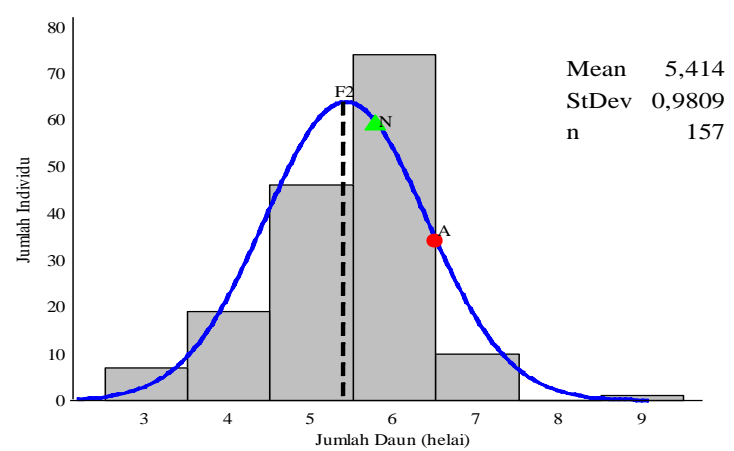

(a)

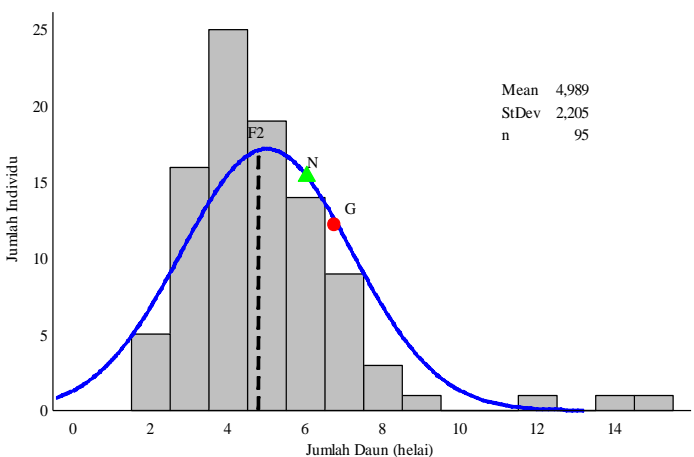

(b)

Gambar 2. Grafik Sebaran populasi F2, untuk karakter jumlah daun (helai) pada persilanagan (a) $\mathrm{Ax} \mathrm{N}$ (b) GxN

Tabel 3. Pendugaan Aksi Gen Karakter Jumlah Daun (helai) melalui Nilai Skewness dan Kurtosis

\begin{tabular}{lllll}
\hline Persilangan & Skewness & Keterangan & Kurtosis & Keterangan \\
\hline Ax N & 0,722 & $\begin{array}{l}\text { aksi gen aditif }+ \\
\text { epistasis } \\
\text { komplementer }\end{array}$ & 1,014 & $\begin{array}{l}\text { Platykurtik+ dikendalikan } \\
\text { banyak gen }\end{array}$ \\
GxN & $1,417 \quad \begin{array}{l}\text { aksi gen aditif }+ \\
\text { epistasis } \\
\text { komplementer }\end{array}$ & 1,543 & $\begin{array}{l}\text { Platykurtik+ dikendalikan } \\
\text { banyak gen }\end{array}$ \\
\hline
\end{tabular}

Hasil pengamatan jumlah daun pada persilangan $\mathrm{AxN}$ (Gambar 2.a) menunjukkan hasil tidak berdistribusi normal. Jumlah individu terbanyak berjumlah 74 individu dengan kisaran jumlah daun 6 helai. Hasil persilangan AxN memperlihatkan rataan jumlah daun 5,414 helai yang lebih rendah dari kedua tetuanya $\mathrm{N}(5,917)$ dan A $(6,500)$. Pendugaan aksi gen (Tabel 3) diketahui nilai skewnees $<0$ menunjukkan grafik sebaran tidak normal artinya aksi gen aditif dengan pengaruh epistasis duplikat dan nilai kurtosis $<3$ yang menunjukkan bentuk grafik platykurtik dimana karakter dikendalikan oleh banyak gen.
Hasil pengamatan jumlah daun pada persilangan GxN (Gambar 2.b) menunjukkan hasil tidak berdistribusi normal. Jumlah individu terbanyak berjumlah 24 individu dengan kisaran jumlah daun 4 helai. Hasil persilangan GxN memperlihatkan rataan jumlah daun 4,989 helai yang lebih rendah dari kedua tetuanya $\mathrm{N}(5,922)$ dan $\mathrm{G}(6,636)$. Pendugaan aksi gen (Tabel 3) diketahui nilai skewnees $>0$ menunjukkan grafik sebaran tidak normal artinya aksi gen aditif dengan pengaruh epistasis komplementer dan nilai kurtosis > 3 menunjukkan bentuk grafik leptokurtik dimana karakter kendalikan sedikit gen. 


\section{Karakter Bobot Kering Akar (g)}

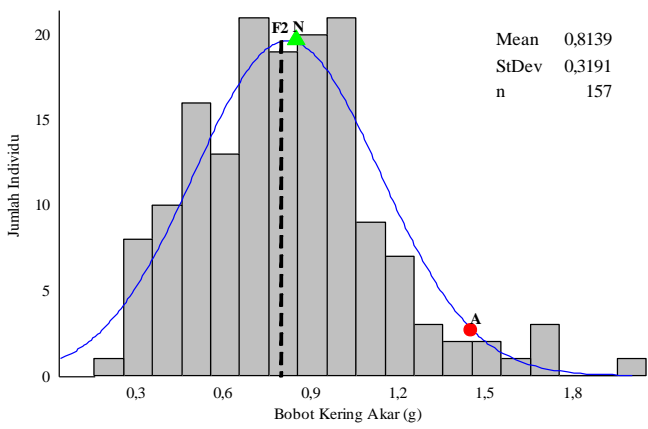

(a)

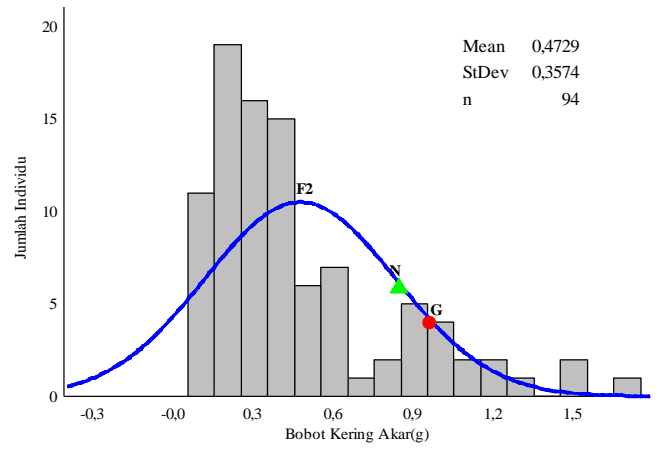

(b)

Gambar 3. Grafik Sebaran populasi F2, untuk karakter bobot kering akar (g) pada persilanagan (a) $\mathrm{Ax} \mathrm{N}$ (b) GxN

Tabel 4. Pendugaan Aksi Gen Karakter Bobot Kering Akar melalui Nilai Skewness dan Kurtosis

\begin{tabular}{|c|c|c|c|c|}
\hline Persilangan & Skewness & Keterangan & Kurtosis & Keterangan \\
\hline $\mathrm{AxN}$ & 0,722 & $\begin{array}{l}\text { aksi gen aditif }+ \\
\text { epistasis }\end{array}$ & 1,014 & $\begin{array}{l}\text { Platykurtik+ } \\
\text { dikendalikan banyak gen }\end{array}$ \\
\hline $\mathrm{GxN}$ & 1,417 & $\begin{array}{l}\text { komplementer } \\
\text { aksi gen aditif }+ \\
\text { epistasis } \\
\text { komplementer }\end{array}$ & 1,543 & $\begin{array}{l}\text { Platykurtik+ } \\
\text { dikendalikan banyak gen }\end{array}$ \\
\hline
\end{tabular}

Hasil pengamatan bobot

Hasil pengamatan bobot

kering akar pada persilangan $\mathrm{AxN}$ kering akar pada persilangan GxN (Gambar 3.a) menunjukkan hasil tidak berdistribusi normal. Jumlah individu terbanyak berjumlah 21 individu dengan kisaran 0,65-0,75 dan 0,95-1,05 g. Rataan hasil persilangan $\mathrm{AxN}$ bobot kering akar 0,814 menunjukkan rataan lebih tinggi dari tetua $\mathrm{N}(0,845 \mathrm{~g})$ dan $\mathrm{A}$ $(1,458 \mathrm{~g})$. Pendugaan aksi gen (Tabel 4) diketahui nilai skewnees > 0 menunjukkan grafik sebaran tidak normal artinya aksi gen aditif dengan pengaruh epistasis komplementer dan nilai kurtosis < 3 menunjukkan bentuk grafik platykurtik artinya karakter dikendalikan oleh banyak gen. (Gambar 3.b) menunjukkan hasil tidak berdistribusi normal. Jumlah individu terbanyak berjumlah 19 individu dengan kisaran 0,15-0,25. Rataan hasil persilangan $\mathrm{GxN}$ bobot kering akar 0,473 lebih rendah dari tetua $\mathrm{N}(0,855 \mathrm{~g})$ dan tetua $\mathrm{G}(0,960 \mathrm{~g})$. Pendugaan aksi gen (Tabel 4) diketahui nilai skewnees $>0$ menunjukkan grafik sebaran tidak normal artinya aksi gen aditif dengan pengaruh epistasis komplementer dan nilai kurtosis < 3 menunjukkan bentuk grafik platykurtik artinya karakter dikendalikan oleh banyak gen. 


\section{Karakter Bobot Biji (g)}

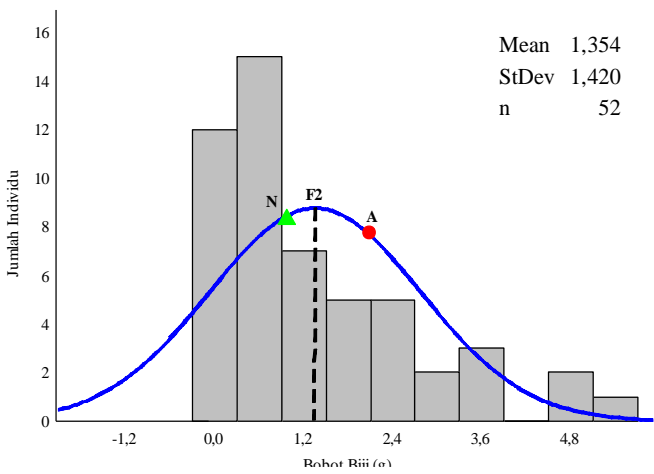

(a)

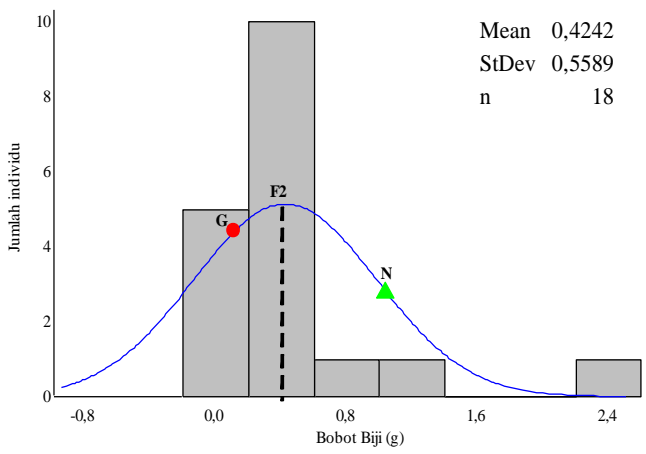

(b)

Gambar 4. Grafik Sebaran populasi F2, untuk karakter bobot biji per tanaman (g) pada persilanagan (a) $\mathrm{Ax} \mathrm{N}$ (b) GxN

Tabel 5. Pendugaan Aksi Gen Karakter Bobot Biji per Tanaman (g) melalui Nilai Skewness dan Kurtosis

\begin{tabular}{|c|c|c|c|c|}
\hline Persilangan & Skewness & Keterangan & Kurtosis & Keterangan \\
\hline $\mathrm{Ax} \mathrm{N}$ & 1,378 & $\begin{array}{l}\text { aksi gen aditif + } \\
\text { epistasis } \\
\text { komplementer }\end{array}$ & 1,270 & $\begin{array}{l}\text { Platykurtik+ } \\
\text { dikendalikan banyak } \\
\text { gen }\end{array}$ \\
\hline GxN & 3,286 & $\begin{array}{l}\text { aksi gen aditif + } \\
\text { epistasis } \\
\text { komplementer }\end{array}$ & 11,637 & $\begin{array}{l}\text { Leptokurtik+ } \\
\text { dikendalikan sedikit } \\
\text { gen }\end{array}$ \\
\hline
\end{tabular}

Hasil pengamatan bobot biji pada persilangan AxN (Gambar 4.a) menunjukkan hasil tidak berdistribusi normal. Jumlah individu terbanyak berjumlah 15 individu dengan kisaran 0,3-0,9 g. Hasil persilangan $\mathrm{AxN}$ diketahui rataan bobot biji 1,354 $\mathrm{g}$ menunjukkan rataan lebih tinggi dari tetua $\mathrm{N}(1,110 \mathrm{~g})$ dan lebih rendah dari tetua A $(2,134 \mathrm{~g})$. Pendugaan aksi gen (Tabel 5) diketahui nilai skewnees $>0$ menunjukkan grafik sebaran tidak normal artinya aksi gen aditif dengan pengaruh epistasis komplementer dan nilai kurtosis < 3 menunjukkan bentuk grafik platykurtik artinya karakter dikendalikan oleh banyak gen.
Hasil pengamatan bobot biji pada persilangan GxN (Gambar 4.b) menunjukkan hasil tidak berdistribusi normal. Jumlah individu terbanyak berjumlah 10 individu dengan kisaran 0,2-0,6 g. Hasil persilangan $\mathrm{GxN}$ diketahui rataan bobot biji $0,4242 \mathrm{~g}$ menunjukkan rataan lebih tinggi dari tetua $\mathrm{N}(1,110 \mathrm{~g})$ dan lebih rendah dari tetua G $(0,303 \mathrm{~g})$. Pendugaan aksi gen (Tabel 5) diketahui nilai skewnees $>0$ menunjukkan grafik sebaran tidak normal artinya aksi gen aditif dengan pengaruh epistasis duplikat dan nilai kurtosis > 3 menunjukkan bentuk grafik leptokurtik artinya karakter dikendalikan oleh sedikit gen. 


\section{Heritabilitas}

Tabel 6. Nilai duga heritabilitas $\mathrm{F}_{2}$ hasil persilangan $\mathrm{AxN}$ dan $\mathrm{GxN}$

\begin{tabular}{lllcl}
\hline Persilangan & \multicolumn{2}{c}{ AxN } & \multicolumn{2}{c}{ GxN } \\
\hline Peubah Amatan & h2 & Kriteria & h2 & Kriteria \\
\hline Tinggi Tanaman $(\mathrm{cm})$ & 0,406 & Sedang & 0,637 & Tinggi \\
Jumlah Daun (helai) & 0,022 & Rendah & 0,810 & Tinggi \\
Bobot Kering Akar $(\mathrm{g})$ & 0,007 & Rendah & 0,776 & Tinggi \\
Bobot Biji $(\mathrm{g})$ & 0,302 & Sedang & 0,822 & Tinggi \\
\hline
\end{tabular}

Nilai duga heritabilitas hasil persilangan $\mathrm{AxN}$ dan $\mathrm{GxN}$ (Tabel 6) menunjukkan kriteria yang beragam. Heritabitas persilangan $\mathrm{AxN}$ Kriteria heritabilitas sedang ditunjukkan oleh peubah amatan tinggi tanaman dan bobot biji. Kriteria heritabilitas rendah ditunjukkan peubah amatan jumlah daun, dan bobot kering akar. Heritabitas persilangan $\mathrm{GxN}$ kriteria tinggi ditunjukkan oleh peubah amatan tinggi tanaman, jumlah daun, bobot kering akar, dan bobot kering akar.

Nilai duga heritabitas dengan kriteria tinggi diartikan keragaman ditentukan oleh genetik. Nilai heritabilitas kriteria sedang diartikan keragaman ditentukan oleh genetik dan lingkungannya. Nilai heritabilitas kriteria rendah diartikan keragaman ditentukan oleh lingkungan. Penelitian Inayah (2014) menjelaskan nilai duga heritabilitas rendah diartikan sebagai keragaman genotipe hasil persilangan kecil sekali atau tidak beragam. Hal ini menunjukkan bahwa terdapat pengaruh lingkungan yang sangat besar terhadap penampilan karakter tersebut.

Heritabilitas dengan kriteria tinggi dapat dijadikan tolak ukur dalam seleksi. Penelitian Widyawati, et al (2014) menyatakan Nilai duga heritabilitas dapat menunjukkan apakah suatu karakter dikendalikan oleh faktor genetik atau faktor lingkungannya, sehingga faktor tersebut dapat diturunkan keturunan selanjutnya. Poehlman (1979) menegaskan salah satu informasi penting yang diperlukan adalah heritabilitas karakter komponen hasil. Nilai heritabilitas merupakan suatu petunjuk seberapa besar suatu karakter atau sifat dipengaruhi genetik atau lingkungan. Pengaruh lingkungan yang kecil menguntungkan dalam melakukan seleksi dikarenakan pada individu tersebut pengaruh genetiknya lebih besar dalam penampilan fenotipenya.

Hasil pengamatan kemenjuluran kurva (skewness) dengan nilai $>0$ mengartikan karakter dikendalikan oleh aksi gen aditif, juga terdapat pengaruh epistatis duplikat didapat pada karakter umlah daun, bobot kering akar, bobot biji pertanaman pada persilangan $\mathrm{AxN}$ dan tinggi tanaman, jumlah daun, bobot kering akar, bobot biji per tanaman pada persilangan $\mathrm{GxN}$, menurut Griffiths et al. (2005) aksi gen aditif merupakan konstribusi dari alel- alel yang menghasilkan fenotipe turunan sama dengan fenotipe tetuannya. Epitatis komplementer interaksi gen akan terjadi dimana fungsi suatu gen akan diperlukan oleh gen lain dalam metabolisme.

Hasil pengamatan keruncingan kurva dengan nilai > 3 bentuk kurva leptokurtik dengan pengaruh karakter dikendalikan oleh sedikit gen didapat pada karakter bobot biji per tanaman pada persilanagn GxN. Karakter yang dipengaruhi sedikit gen menyebabkan karakter mempunyai kemungkinan yang lebih besar untuk diturunkan kepada anakannya. Karakter bobot biji pada hasil persilangan GxN mempunyai kemungkinan yang besar untuk diturunkan kepada keturunannya ini 
ditambahkan dengan pendugaan aksi gen aditif ditambah epistatis komplementer dan karakter yang dikendalikan oleh sedikit gen.

Morfologi hasil penelitian karakter tinggi tanaman, jumlah daun dan bobot kering akar dapat dilihat lebih dipengaruhi oleh kondisi lingkungan, diketahui konsentrasi garam dapat menurunkan tinggi tanaman, jumlah daun, bobot kering akar, dan bobot biji per tanaman. Hal ini diketahui dari banyaknya jumlah individu yang dibawah niali rata- rata hasil pengamatan. Penelitian Nugraheni et al. (2013) menjelaskan pengaruh salinitas tinggi pada tanaman Crotalaria juncea L. menunjukkan pertambahan tinggi tanaman yang semakin menurun, yang diduga disebabkan oleh terlarutnya garam sehingga menurunkan potensial air, yang berakibat tanaman sulit menyerap, rusaknya membran sel, yang menyebabkan sifat selektivitas membran sel berkurang. Keadaan ini dapat mengakibatkan pengambilan ion menjadi berlebih dan dapat meracuni tanaman, sehingga dapat menghentikan pertumbuhan sel.

Hasil penelitian memperlihatkan tanaman peka salinitas mengalami penurunan pertumbuhan akan mengalami penurunan produktifitas. Pengaruh salinitas pada tanaman kedelai menurunkan tinggi tanaman, daun cepat mengalami kerontokan dini (senescence), penurunan total biomasa, dan hasil produksi. Menurut Kristiono et al. (2013) penurunan biomasa diatas tanah lebih tinggi dari pada akar. Penurunan bobot kering akar yaang disebabkan oleh menurunnya potensial tanah. Potensial tanah yang rendah menyebabkan air tanah air tanah menjadi tidak tersedia bagi tanaman dan tanaman mengalami kekeringan fisiologis. Air dibutuhkan tanaman untuk turgor sel dan proses fotosintesis. Tanaman yang tidak mendapatkan air yang cukup maka turgor sel rendah dan stomata akan menutup. Penutupan stomata menyebabkan suplai $\mathrm{CO}_{2}$ terhambat sehingga mengakibatkan penurunan proses fotosintesis.

Tanaman peka salinitas diketahui mengalami penurunan bobot kering akar. Bobot kering akar merupakan akumulasi dari proses akumulasi dari fotosintesis yang mengakibatkan penurunan bobot kering tanaman. Penurunan bobot kering genotipe kedelai tesebut diperkuat dengan hasil penelitian Aini, et al (2014) bahwa salinitas berpengaruh pada pertumbuhan tanaman kedelai dan hasil produksinya. Peningkatan kadar $\mathrm{Na} \mathrm{Cl}$ berpengaruh pada penurunan bobot kering akar dan bobot kering total pada tanaman kedelai. Dalam penelitiannya Farid dan Sjahril (2006) tanaman yang toleran terhadap salin juga mampu mencapai keseimbangan termodinamika tanpa terjadi kerusakan jaringan yang berarti, karena tanaman dapat menyesuaikan tekanan osmotik selnya untuk terjadinya dehidrasi.

Karakter morfologi tanaman
dengan pengaruh
menjelaskan mekanisme retahanan
tanaman terhadap salinitas bervariasi
antara spesies dan varietas dari tingkat
yang paling rentan sampai paling tahan,
ini merupakan tanggapan tanaman
terhadap lingkungan salin.

\section{SIMPULAN}

Pada cekaman salinitas karakter morfologi mengalami penurunan pertumbuhan dan produktifitas.

Pendugaan pewarisan genetik yang besar kemungkinan diwariskan kepada turunannya dilihat dari hasil persilangan GxN hal ini dapat dilihat dari parameter tinggi tanaman, jumlah daun, bobot kering akar, dan bobot biji pertanaman 


\section{SARAN}

Penelitian lanjutan perlu dilakukan untuk melihat berapa besar karakter morfologi yang diwarikan sehingga didapatkan genotipe yang diinginkan

\section{DAFTAR PUSTAKA}

Acquaah, G. 2007. Principles of Plant Genetics and Breeding. First Published. Blackwell Publishing Ltd. Australia.

Adie, M. M. dan Krisnawati, A. 2013. Keragaan Hasil dan Komponen Hasil Biji Kedelai Pada Berbagai Agroekologi. Prosiding Seminar Hasil Penelitian Tanaman Aneka Kacang dan Umbi. 2013. Malang: Pemulia Kedelai Balitkabi.

Aini, N., Sumiya, W. D. Y., Syekhfani., Dyah, R. P. dan Setiawan, A. 2014. Kajian Pertumbuhan, Kandungan Klorofil dan Hasil Beberapa Genotipe Tanaman Kedelai (Glycine max L.) Pada Kondisi Salinitas. Prosiding Seminar Nasional Lahan Sub Optimal; Palembang, 26-27 September 2014. Palembang. ISBN : 979-587-529-9: 591-597

[BPPP] Badan Pengembangan Penelitian dan Pengembangan Tanaman Pangan. 2007. Deskripsi Kedelai Varietas Anjasmoro. Bank Pengetahuan Tanaman Pangan Indonesia.http://www.puslittan. bogor.net/index.php

[FAO] Food and Agriculture Organization. 2013. Crop Description.Climate and Water Information ofSoybean. http://www.fao.org/nr/water/cro pinfo_soybean.html $[7$ Jan2015].
Farid, M. dan Sjahril, R. 2006. Mekanisme Ketahanan Kedelai Terhadap Salinitas dan Kekeringan Berdasarkan Karakter Morfologis. Buletin Penelitian ISSN 0215-1748, 9(2):146-153.

Griffiths, A. J. F., Wessler, S. R., Lewontin, R. C., Gelbart, W. M., Suzuki, D. T., and Miller, J. H. 2005. Introduction to Genetic Analysis. New York (US): W.H Freeman.

Inayah, I. 2014. Analisis Parameter Genetik dan Deteksi Segregan Transgresif Pada Dua Populasi $\mathrm{F}_{2}$ Persilangan Kacang Tanah (Arachis hypogaea L.) [Skripsi]. Bogor: Institut Pertanian Bogor

Kristiono, A., Purwaningrahayu, R. D. dan Taufiq, A. 2013. Respon Tanaman Kedelai, Kacang Tanah, dan Kacang Hijau terhadap Cekaman Salinitas. Buletin Palawija. 26: 45-60

Nugraheni, I. T., Solichatun, E. dan Anggarwulan. 2003. Pertumbuhan dan Akumulasi Prolin Tanaman Orok-orok (Crotalaria junceaL.) pada Salinitas $\quad \mathrm{CaCl}_{2}$ Berbeda. Biosmart. 5(2). Surakarta: Universitas Sebelas Maret.

Pathan, S.M.D., Lee, J., Shannon,J.G. and Nguyen, H.T. 2007. Recent advances in breeding for drought and salt stress tolerance in soybean (Chapter 30). In: M.A. Jenks et al. (Eds.). Advances in molecular breeding toward drought and salt tolerant crops. p.739-773

Poehlman, J.M. 1979. Breeding Field Crops. Ed ke-2. Connecticut: The AVI Publishing, Westport. 486p.

[PUSLITTAN] Pusat Penelitian dan Pengembangan Tanaman Pangan. 2015. Varietas 
Grobogan.

http://www.puslittan.bogor.net/i ndex.php [13 Feb 2015].

Sobir dan Syukur, M. 2015. Genetika Tanaman. IPB Press, Bogor, Indonesia.

Sopandie, D. 2014. Fisiologi Adaptasi Tanaman terhadap Cekaman Abiotik pada Agroekosistem Tropika. IPB Press, Bogor, Indonesia.

[USDA] United States Department of Agriculture. 2015. Natural Resources Conservation Service. Plant Database. http://plants.usda.gov/java/Clas
sificationServlet . [10 Januari 2015].

Welsh, J. R. 1991. Fundamental of Plant Genetic and Breeding (Dasardasar Genetika dan Pemuliaan Tanaman ahli bahasa Mogea, J.P) Jakarta: Erlangga.

Widyawati, Z., Yuliana, I. Dan Respatijarti. 2014. Heritabilitas dan Kemajuan Genetik Harapan Populasi Pada $\mathrm{F}_{2}$ Pada Tanaman Cabai Besar (Capsicum Annum L). Produksi Tanaman. 2(3): 247-252. 